\title{
Growth Hormone Response to Clonidine in Nondepressed Patients with a History of Suicide Attempts
}

\author{
William Pitchot, Michel Hansenne, Antonio Gonzalez Moreno, and Marc Ansseau
}

Key Words: Depression, suicide attempt, clonidine test, noradrenergic system

\section{Introduction}

The prevailing neurochemical theory about biological correlates of suicidal behavior focuses on the serotonergic system (Asberg et al 1987); however, several data are available about the implication of the noradrenergic system in the control of inwarddirected aggression. In 1976, Beskow et al showed a decrease of norepinephrine levels in the putamen of suicide victims. Betaadrenergic receptors have been found significantly increased, decreased, or unchanged in the frontal cortex of suicide victims (review in Little et al 1993). Recently, Meana et al (1992) reported an increased presynaptic alpha2-adrenergic receptor sensitivity in the brain of suicide victims. Secunda et al (1986) showed smaller urinary outputs of the norepinephrine metabolite 3-methoxy-4-hydroxyphenylglycol (MHPG) and a lower plasma concentration of MHPG in suicide attempters compared to patients without history of suicidal behavior. Cerebrospinal fluid (CSF) studies have also provided additional data for the noradrenergic hypothesis of suicidal behavior but with controversy. Brown et al (1979) found higher levels of CSF MHPG in personality disorder patients with a history of suicide attempt than in controls. Agren (1980) reported a negative correlation between measures of suicidal tendencies and CSF MHPG levels in depressed patients. In 1993, Träskman-Bendz et al showed an increase CSF MHPG in violent suicide attempters. More recently, we suggested an involvement of the noradrenergic system, particularly alpha2-adrenergic function, in the expression of suicidal behavior by demonstrating a smaller growth hormone $(\mathrm{GH})$ response to clonidine, an alpha2-adrenergic agonist, in

From the Psychiatric Unit, University of Liège Medical School, Liège, Belgium. Address reprint requests to William Pitchot, M.D., Psychiatry Unit, University of Liège Medical School, C.H.U. dui Sart Tilman, B-4000 Liège, Belgium. depressed patients with a history of suicide attempts in comparison to nonattempters (Pitchot et al 1994). This study raised the hypothesis that a hyposensitivity of postsynaptic alpha2-adrenergic receptors could be a determinant of suicidal behavior; however, this relationship between a blunted GH response to clonidine and suicidality could be observed in depressed patients only, but not in other diagnostic categories. In the present study, in order to test this hypothesis, GH responses to intravenous clonidine challenge were measured in nondepressed patients with a history of suicide attempts.

\section{Methods}

\section{Subjects}

The study was performed in 18 nondepressed male patients with a score less than 12 on the 17 -item Hamilton depression scale (Hamilton 1960). This score was mainly due to aspecific symptoms such as psychic and somatic anxiety, insomnia, or somatic complaints. The DMS-III-R clinical diagnoses of the patients were personality disorder ( 3 cases), anxiety disorder ( 7 cases), and adjustment disorder ( 8 cases). The patients were subgrouped into suicide attempters $(n=7)$ and nonattempters $(n=11)$. The two groups did not differ in mean age or weight. The clonidine test was performed after a drug-free period of at least 2 weeks. Moreover, there was no significant difference in washout periods between the two groups.

Past history of suicide attempt was based on interviews with the patients and their family members. All patients were free of medical illness as evidenced by history, medical examination, electrocardiogram, chest X-ray, electroencephalogram, and routine laboratory tests. Patients with a basal systolic blood pressure less than $100 \mathrm{mmHG}$ were excluded from the study. Moreover, to be included, patients had to present a basal ( $\mathrm{t} 0$ ) $\mathrm{GH}$ level less 
than $5 \mathrm{ng} / \mathrm{ml}$ before the pharmacological challenge (Ansseau et al 1984). The exclusion of subjects with basal $\mathrm{GH}$ values $>5 \mathrm{ng} / \mathrm{ml}$ was recommended by Laakmann (1990) who demonstrated that "prestimulator" healthy volunteers responded significantly less to a noradrenergic challenge than healthy volunteers with low basal values. Finally, the protocol was approved by the Ethical Committee of the University of Liège Medical School, and all patients were fully informed of the study and gave their consent.

\section{Neuroendocrine Test Procedure}

The clonidine test was performed in all subjects at bedrest after an overnight fast. At $7 \mathrm{AM}$, an indwelling catheter was inserted in a forearm vein. Blood samples of $10 \mathrm{ml}$ were collected at -20 , $0,+20,40,60$ and 120 minutes after injection at $8 \mathrm{AM}$ of clonidine, $0.15 \mathrm{mg}$ diluted in saline to obtain $20 \mathrm{~mL}$ intravenously in 10 minutes.

GH was measured with a double antibody radioimmunoassay (Franchimont 1968), with intraassay and interassay coefficients of variation of, respectively, $13.3 \pm 4.7 \%$ and $14.8 \pm 9.6 \%$ and a detection limit of $0.2 \mathrm{ng} / \mathrm{ml}$.

\section{Data analysis}

$\mathrm{GH}$ responses to clonidine were measured by $\mathrm{GH}$ peak values following injection. Analyses were performed using absolute $\mathrm{GH}$ values as well as differences related to basal $(t 0)$ levels (relative values). Since the correlations between absolute and relative values were very high $(r>0.98)$, only absolute values are reported here. Because $\mathrm{GH}$ responses to clonidine were not normally distributed, GH values were log-transformed. The responses of patients with and without a history of suicide attempts were compared by analysis of covariance (ANCOVA) for age.

\section{Results}

Mean GH peak responses to clonidine did not differ between suicide attempters and nonattempters: (mean $\pm \mathrm{SD}$ ) for $\mathrm{GH}$ peak, $5.07 \pm 6.0 \mathrm{ng} / \mathrm{ml}$ vs $9.0 \pm 9.2 \mathrm{ng} / \mathrm{ml}, F=0.17$, df $=3,15$, $p=0.69$, and for the $\log \mathrm{GH}$ peak values, $F=0.43$, $\mathrm{df}=3,15$, $p=0.53$. On the basis of a defined cutoff value of $5 \mathrm{ng} / \mathrm{ml}$, five patients in the group of suicide attempters and four in the group

\section{References}

Agren H (1980): Symptom patterns in unipolar and bipolar depression correlating with monoamine metabolites in the cerebrospinal fluid: II. Suicide. Psychiatry Res 3:225-236.

Ansseau M, Scheyvaerts M, Doumont A, Poirrier R, Legros JJ, Franck G (1984): Concurrent use of REM latency, dexamethasone suppression, clonidine and apomorphine tests as biological markers of endogenous depression: A pilot study. Psychiatry Res 12:261-272.

Asberg M, Schalling D, Träskman-Bendz L, Wagner A (1987): Psychobiology of suicide, impulsivity, and related phenom- of nonattempters presented a blunted $\mathrm{GH}$ response $\left(x^{2}=2.1\right.$, $\mathrm{df}=1, p=0.15$ ).

\section{Discussion}

The results of the present study do not confirm a specific role for alpha2-adrenergic receptors in the control of suicidal behavior. Indeed, mean $\mathrm{GH}$ peak responses to clonidine did not exhibit any significant difference between nondepressed suicide attempters and nonattempters. Moreover, a blunted $\mathrm{GH}$ response to clonidine did not appear to be a reliable "biological marker" of suicidal behavior.

Our results are at variance with previous studies showing a trend for a decrease of noradrenergic activity in depressed patients with a history of suicidal behavior. In 1982, Ostroff et al found a lower 24-hour urinary norepinephrine-to-epinephrine ratio in three depressive patients with a history of severe suicide attempts compared to depressed controls without history of suicidal behavior. Secunda et al (1986) reported low urinary and plasma MHPG measures in suicide attempters compared to controls. CSF MHPG levels exhibited a similar trend only in bipolar patients (Secunda et al 1986). More specifically, recently, we found a blunted $\mathrm{GH}$ response to clonidine in major depressed patients with a history of suicide attempts compared to nonattempters (Pitchot et al 1994). Trestman et al (1993) have also found a relationship between a reduced noradrenergic activity as assessed by GH responses to clonidine and self-directed aggressiveness in major depression; however, the results of our study are in agreement with a study of Roy et al (1989) who did not find any relationship between CSF, urinary, and plasma indices of noradrenergic function and history of suicide attempt. Moreover, recently, in a sample of 22 major depressed male inpatients with a history of suicide attempts compared to 22 age-matched nonattempters, we failed to replicate our initial observation of an association between a blunted GH response to clonidine and suicidality (Pitchot et al in press).

In conclusion, noradrenergic disturbances, particularly at the level of alpha2-adrenergic receptors, seem to play a minor role in the biology of inward-directed aggression. In fact, suicidal behavior could be associated with a blunting of $\mathbf{G H}$ response to clonidine in depression only, and not in other psychiatric disorders. ena. In: Meltzer HY (ed), Psychopharmacology: Third Generation of Progress. New York: Raven Press, pp 655-668.

Beskow J, Gottfries C, Roos B, Winblad B (1976): Determination of monoamine and monoamine metabolites in the human brain: Postmortem studies in a group of suicides and in a control group. Acta Psychiat Scand 53:7-20.

Brown GL, Goodwin FK, Ballenger JC, Goyer PF, Major LF (1979): Aggression in humans: Correlates with cerebrospinal fluid amine metabolites. Psychiatry Res 1:131-139.

Franchimont P (1968): Le dosage radio-immunologique de 
l'hormone de croissance humaine. Cahiers Médicaux Lyonnais 44:887-898.

Hamilton M (1960): A rating scale for depression. I Neurol Neurosurg Psychiatry 23:56-62.

Laakmann G (1990): Psychopharmacology and depression research. Berlin: Springer-Verlag.

Little KY, Clark TB, Ranc J, Duncan GE (1993): Beta-adrenergic receptor binding in frontal cortex from suicide victims. Biol Psychiatry 34:596-605.

Meana JJ, Barturen F, Garcia-Sevilla JA (1992): Alpha-2adrenoreceptors in the brain of suicide victims: Increased receptor density associated with major depression. Biol Psychiatry 31:471-490.

Ostroff R, Giller E, Bonese K, Ebersole E, Harkness L, Mason J (1982): Neuroendocrine risk factors of suicidal behavior. Am $J$ Psychiatry 139:1323-1325.

Pitchot W, Ansseau M, Gonzalez Moreno A, Wauthy J, Hansenne M, von Frenckell R (1994): Relationship between alpha-2-adrenergic function and suicidal behavior in depressed patients. Psychiatry Res 52:115-123.

Pitchot W, Hansenne M, Gonzalez Moreno A, Wauthy J, Ansseau M: Biological basis of suicidal behavior: Neuroendocrine and psychophysiological approach of the role of catecholamines. Acta Psychiatrica Belgica (in press).

Roy A, Pickar D, De Jong J, Karoum F, Linnoila M (1989): Suicidal behavior in depression: Relationship to noradrenergic function. Biol Psychiatry 25:341-350.

Secunda S, Cross C, Koslow S, Katz M, Kocsis J, Maas J, Landis $H$ (1986): Biochemestry and suicidal behavior in depressed patients. Biol Psychiatry 21:756-767.

Träskman-Bendz L, Alling C, Alsén M, Regnéll G, Simonsson P, Öhman R (1993): The role of monoamines in suicidal behavior. Acta Psychiatr Scand 371 suppl.:45-47.

Trestman RL, deVegvar M, Coccaro EF, Siever LJ (1993): Depression and personality disorder: Differential biology of aggression and suicide. Neuroendocrinology Letters 15:353. 